\title{
Cognitive aspects of touch as a source of linguistic reflection
}

\section{[Kognitivní aspekty hmatu a doteku jako zdroje jazykových reflexí]}

\author{
Jiri Korostenski
}

\section{DOI: 10.18355/XL.2017.10.02.11}

\begin{abstract}
Abstrakt
Cílem článku je analyzovat proces vzniku a výsledky jazykových reflexí v konkrétní zdrojové oblasti hmatu, a to vše v česko-ruském srovnání. Vzájemné souvislosti mezi nimi mají různou povahu. Zdá se, že shodný zdroj hmatových vjemů přispívá k tvorbě omezeného počtu konceptuálních metafor ve shodných schématech, jako např. ,nádoba' nebo ,potrubí'. Často nejsou pojmově ani sémanticky v mezijazykovém srovnání totožné. Shodná konceptuální schémata jsou často slovotvorně odlišná.
\end{abstract}

Klíčová slova: jazykové reflexe, zdrojová oblast, hmat, česko-ruské srovnání, konceptuální metafory a schémata.

\section{Úvod}

Kognitivní směr v jazykovědě se $\mathrm{v}$ současnosti stal pevnou součástí nejen americké, ale i evropské lingvistiky. Americké pojetí vychází z modelu jazykového obrazu světa, odvozených kognitivních metafor v pojetí J. Lakoffa, M. Johnsona (2002:11), J. Langackera (1987) a na bázi prototypické kategorizace jevů E. Roschové (1977:15), v němž rozhodující úlohu zaujímá pojmový systém člověka. Nejenom řídí a ovlivňuje myšlení, ale rozhodujícím způsobem strukturuje a vytváŕí předpoklady pro metaforické myšlení a následné ztvárnění pojmových struktur $\mathrm{v}$ podobě jazykových reflexí a řečového vyjadřování. Selektivnost tak zůstává nejpodstatnějším konstitutivním prvkem modelů jazykového obrazu světa. Ve výsledku nejsou tyto principy strukturace objektu pojmenovány a nehrají rovněž podstatnou roli, což se odráží v návazných významových souvislostech. Př́íkladem může být i barevná stálost objektů, která se „nepromítá“ do lexikálního významu, stejně jako difúznost různých významových struktur v procesech prototypické organizace slovní zásoby, srv. např̀. E. Roschová (1977), I. Bartoš (2007).

V pracích kognitologů (Janda 2004, Langacker 1987 aj.) se zmíněné názory objevily v různém stupni rozpracovanosti. Nicméně lze pozorovat značnou shodu v tom, že jde o hierarchizované uspořádání konceptualizovaných entit ve smyslu jejich obsahu i konkrétní funkce a úkolů, které plní. Lze dovodit, že zde hovoříme o konceptech stěžejních (základních), mezi něž patří zcela nepochybně ty, které „kumuluji““ konkrétní lidské zkušenosti z bezprostředního a každodenního kontaktu člověka s praxí.

Ruský a obecně východoevropský vývoj kognitivní lingvistiky navazuje na tradiční lingvokulturologická a kulturologická studia. Na rozdíl od středoevropského a amerického přístupu ruské pojetí konceptu ve většině prací z kognitivní lingvistiky stalo ústřední a relativně velmi stabilní strukturou myšlení, související s jazykovými reprezentacemi, ale nenahrazující pojem v Ogden-Richardsově trojúhelníku v řetězci slovo - předmět - pojem. Koncept se v jejich pojetí spolupodílí na tvorbě jazykového obrazu světa (Alefirenko 2010:191 n.) a vstupuje s nim do složitých interakcí. Výsledkem jsou pak jazykové realizace etnokonceptů. Ani tento př́stup, beroucí v úvahu celou řadu proměnných faktorů, nebyl schopen zobecnit byt' alespoň základní 
algoritmus „prognózování“ jazykových realizací za určitých předem vymezených podmínek. Preciznost a rozpracovanost vztahů konceptu k okolí tak ostře kontrastovala s reálnými výsledky v oblasti jazykových realizací. Proto v současnosti dochází v ruské lingvistice k reflexi stavu a kritice uvedeného pojetí konceptu (Rachilina 2010: 15). Dle jejího pohledu koncept jako funkční typ neexistuje, poněvadž průkaznosti odporují dosažené experimentální výsledky s jeho sémantikou, v nichž využila přívlastkových konstrukcí odpovídajících jmen s adjektivem hluboký/глубокий, genitivu míry, komitativu a spojení s předložkou v/в prostorového významu. Prototypické kategorizaci mimojazykové reality dominovalo zpočátku pojetí konceptuálních metafor, nicméně $\mathrm{v}$ současnosti lze pozorovat v tomto úseku kognitivního výzkumu určité sbližování výše uváděných východisek. Proto se např. užívá pojmu topologického (obrazného) schématu jako součásti analýzy metaforického odrazu mimojazykové skutečnosti. Metaforu pak lze považovat za výsledek správného pochopení jevů a faktů z určité oblasti (cílové) na pozadí oblasti jiné (zdrojové) (Воронина 2012: 55).

V české jazykovědě se dlouhodobě kognitivními výzkumy zabývá I. Vaňková. Vychází z polské kognitivní jazykovědy Je. Bartmiňského (2009) o jazykovém obrazu světa a etnolingvistických stereotypech. I. Vaňková předpokládá, že schopnost řeči tematizovat vytváŕí velmi dlouhé a složitě propojené, zpravidla metaforicky, řetězce různých konceptualizací, jako např. vody a vodního toku, společné cesty nebo lidských orgánů (Vaňková 2007: 8, 9). Konkrétní jazykové obrazy strachu (Saicová Ŕímalová 2007: 13 n.), vody (Nebeská 2007: 19 n.) a další jsou již pro češtinu zpracovány jako dílčí fragmenty jazykového obrazu. Zmíněné konceptualizační oblasti se stávají zdrojem a počátkem konceptualizačního procesu, ukončeného obvykle v cílové jazykové realizaci metaforou určitého typu. Česká kognitivní škola pracuje s východisky jazykového obrazu světa a navazující plynulé konceptualizace, přičemž je zdůrazněn kolektivně sdílený aspekt kognitivního prvku v jazyce.

V naší práci sdílíme český pohled na kognitivní procesy v přirozených jazycích s tím, že současně uznáváme význam slovotvorné dynamiky a nominace pro kognitivní výzkumy. Cílem naší práce je analyzovat zpo̊soby jazykových reflexí v kognitivních procesech dvou jazyků, a to češtiny a ruštiny, provést srovnání dílčího segmentu jazykových reflexí češtiny a ruštiny, opírající se o zdrojovou oblast hmatu, s níž bezprostředně souvisí dotek nejenom jako zdroj vnímání, ale i výchozí bod transformací směřujících $\mathrm{k}$ jazykovým realizacím. $\mathrm{V}$ řadě případů jazykové reflexe nabývají metaforické povahy. V další analýze a klasifikace byl materiál řazen do struktur podle typologie výchozího smyslového vjemu a mezijazykově srovnáván. Zdrojem jazykového materiálu pro analýzu byly jak české, tak ruské slovníky výkladové, překladové, frazeologické, sémantické a etymologické, přičemž sledovaný materiál rozsahově zahrnoval zdrojové a pojmové sekvence se souvisejícími taktilními vjemy.

Mechanizmus kognitivních změn považujeme za kontinuální a neustálý proces, opírající se o nejrůznější zdrojové oblasti v lidském myšlení a psychice a směřující do oblasti cílového jazykového vyjádření. Spolu s I. Vaňkovou (2007) považujeme lidské smysly za jednu ze zdrojových oblastí, z níž počáteční vjemy nabývají pojmových a konceptualizačních hodnot.

Postupy jazykových realizací se pak staly předmětem srovnávací analýzy $\mathrm{v}$ obou jazycích. Proto srovnávací výzkum kognitivních procesů v obou jazycích zahrnuje nejen analýzy kognitivních postupů v obou jazycích, ale zahrnuje rovněž srovnávací pohledy na funkcionální a sémantické odlišnosti slovotvorných prostředků $\mathrm{v}$ cílových jazykových realizacích. Kognitivní potenciál slovotvorných prostředků je ukryt i v pojmenovacích procesech, nicméně je zatím využíván málo. Problematiku 
srovnávacích aspektů kognitivního potenciálu slovotvorných modelů na př́kladu slovenštiny a ruštiny nastínila N. Korina (2012). Došla k závěru, že k rekonstrukci naivního modelu světa mohou významně přispět právě kognitivní potence slovotvorných prostředků, čímž lze objasnit i vztahy mezi různými jazykovými a pojmovými kategoriemi (Korina 2012: 80).

Současná věda rozeznává zpravidla pět tradičních smyslů: zrak, hmat, sluch, čich a chut'. Taktilní počitky a vjemy jsou zprostředkovány specifickými receptory lidského těla. Vedle počitků zrakových jsou chápány jako druhý nejvýznamnější zdroj lidského poznání okolního světa. I v literatuře (Vaňková a kol. 2005: 163 n.) se dnes takové pojetí objevuje velmi často. V uvedené souvislosti je nutné si připomenout význam hmatu a doteku jako podstaty taktilního vnímání pro smysluplný život např. nevidomých lidí. Zdravý člověk si tyto souvislosti uvědomí např. až za naprosté tmy, v níž vizuální orientace selhává. Následné informace člověk přijímá a vytváří si představy o okolí pouze dotekem a hmatem (Korostenski 2011). Uvedené perceptivní podněty vznikají na základě reálného fyzického kontaktu s okolím. Jen tak lze vysvětlit spojení: ....ani jsem se ho nedotkl...; ...nech mě na to sáhnout...; ...musím si vše nejprve ohmatat (osahat) a pak ti řeknu... apod.

\section{Taktilní činnost z hlediska pojmového a jazykového}

Po doteku hmatem zjistíme, zda je něco ,studené', ,teplé‘, popř. ,bolestivé‘. Nicméně šíře ,informačni“ škály „sémantických“ možností těchto počitků je nesrovnatelně pestřejší nejenom ve smyslu přesnější specifikace např. teploty, jako ,vroucí", ,horké‘, vlažné‘, ,chladné', ,studené‘, ,ledové‘ vody apod., ale i dalších fyzikálních charakteristik povrchu předmětů, srov.: ,vlhký', ,drsnýc, ,hrubý', ,hladký', ,mokrýc, ,jemný', ,hebký‘ apod.. Můžeme dokonce definovat tvary předmětů, které vnímáme pouhým dotekem a hmatem, srov. např.: ,protáhlý,, ,zaoblený', ,kulatý', ,šišatý', ,ostrý‘, ,tupý‘, ,špičatý‘, ,hranatý‘ atd.

O významu hmatu prostřednictvím doteku pro náš systém poznání svědčí i způsob identifikace pohybů vlastního těla, které mohou být mimovolné, ale i cíleně zaměřené na určitou oblast poznání. Dotekem a hmatem tak zjistíme např́klad to, zda nás bolí nějaký vnitřní orgán, zub či pracuje srdce (tlukot), funguje krevní oběh (tep), jak nám povyrostly vlasy, vousy, nehty apod.

Bohatě strukturovaný systém členění pojmů je na jazykové úrovni reflektován výrazy, které jsou zdrojovou oblastí pro cílové sféry četných metaforizovaných významů. Nejvíce se týkají procesů ,vnímáni", ,poznání, ,mentálních aktivit', ,mezilidských a společenských vztahư'. Pro formování pojmů a představ je pak důležité, že taktilní procesy jsou podle specifika svého zaměření organizovány do dílčích struktur, což je reflektováno i ve specifických slovotvorných prostředcích. Jde o způsoby hmatu: pro-hmat-a-t, o-hmat-a-t, na-hmat-a-t. Ty již zrretelně aktivizují v určitých momentech konceptualizační schémata, např. ,nádoby“ a reflektují její vnitřní prostor, srov. např.: ...prohmatal zevrubně dutinu bř̌̌s̆í...(врач ощупал брюшную полость) a ...zjištóoval př́činu bolesti vnitřnich orgáni̊..., ale i pohyb po povrchu: na dně nahmatal kámen (SSJČ III 1989: 196) (на дне нашупал камень); ohmatal ostř́ zbraně (...он ощупал/охватил лезвие ножа) а оhтаtala krajinu ос̌ima [SSJČ III 1989: 519]) (..она охватила местность взглядом). Nicméně jazykový obraz češtiny reflektuje i samotný výsledek této činnosti, zejména v podobě adjektiv a adverbií, srov.: puls je nehmatný; cukroví se nám zdálo ohmatané; nejcitlivějši místo hmatu je na špičce jazyka; výzkum přinesl prvni hmatatelné výsledky; hmatatelně cítil svou bídu (SSJČ II 1989: 49) (пульс неощутим, пирожки нам показались захватанными, самое чувствительное место осязания находится в кончике 
языка ..., исследования принесли ощутимые результаты, остро чувствовать нужду ...). Slovotvorně jsou s nimi spojeny i deriváty substantivní, jako např.: hmaták, hmatáč, hmatadlo, hmatník a další. V některých př́ípadech jsou metaforizované významy vázány na specifickou spojitelnost, srov. např. hmatatelný (dostavily se prvni hmatatelné výsledky). Zpravidla jde o metaforizovaná užití na rozdíl od nehmatný (puls byl nehmatný).

V obou jazycích vystupují jako zdrojové sféry některé orgány hmatu, jako např. ruka (рука), noha (нога), jazyk (язык), loket(локоть) apod, ale podrobný rozbor jsme provedli pouze v př́padě slova ruka.

\section{Ruka jako zdrojová sféra jazykových reflexí}

Pohyb ruky, provedený s cílem realizace vjemového počitku hmatem, je $\mathrm{v}$ češtině strukturován $\mathrm{z}$ hlediska prostorové lokalizace různě, zpravidla bez stanovení horizontální, ale i vertikální osy. V případě typu sáhnout, vysáhnout (docmamb), srv. např: svice vosková tak dlouhá, jak já mohu od země vysáhnouti (SSJČ [VII] 1989: 330) jde o význam př́mý. V metaforizovaných významech je pohyb rukou často konceptualizován z perspektivy vztahu $\mathrm{k}$ hranici plošně, např. zámezí, mimo určité meze', soumezné vědy ,se společnými předměty / mezemi zájmu'; zamezit, nedovolit překonat určitou mez'. Cílená lokalizace doteku však může určitou hranici překročit nebo naopak nepřekročit či zasáhnout předmět jako celek nebo naopak pouze jeho určitou část, např. přesáhnout, dotknout se něčeho za stanovenou mezí; prrehmátnout ,hmatem ruky přjít za stanovenou mez'; nedosáhnout / nedohmátnout, ukončit pohyb ruky před stanovenou mezí; obsáhnout, obemknout prsty / rukama určitý objekt'; ohmatat ,hmatáním obsáhnout vnější povrch“ ,nádoby'; zasáhnout ,umístit něco do vymezeného prostoru'. Ve zdrojové oblasti zmíněného typu se vytvářejí základy, z nichž v cílové sféře vznikají metaforizované abstraktní významy, odrážející se v konkrétních výrazech, spojené s mentální sférou člověka, srov.: významový presah; ...dosah svých slov si plně neuvědomoval..., ...nepodařilo se mu nahmatat souvislosti dávného príběhu..., ale cílovou sférou může být také ,poznání, srov.: obsáhl pohledem celý kraj (SSJČ [III] 1989: 426), popř. ,pochybení pracovníků $v$ minulosti již došlo k několika přehmatům úředníkỉ.

V ruštině se na úrovni sloves systém vyjádření doteku s češtinou částečně shoduje. Proto je vertikální orientace slovesa neutrálního významu dоcmaвamb, stejně jako v češtině pro posluchače / čtenáře zřejmá až z kontextu, srov.: Он рукой еле доставал до потолка помещения. (Rukou sotva dosáhl na strop místnosti.). Nespecifikovaná jsou $\mathrm{v}$ ruštině i vyjádření lokalizace na povrchu plošného nebo prostorového útvaru. Etymologicky a sémanticky se jedná zejména o deriváty od kořene -кас-, -трон-, které ve srovnání s češtinou vyjadřují dílčí operace procesů a stavů ,doteku', ,uchopení, ,držení‘ a ,lokalizace doteku“ ve vymezeném prostoru ,nádoby‘ poněkud jinak. Např. ,letmý (lehký) dotek‘ vyjadřuje sloveso прикоснуться, srov.: Правитель прикоснулся двумя пальиами к орденскому крестy vladař se lehce dotkl dvěma prsty řádového kř́že. Rovněž u slovesa дотронуться je ve spojení ...но стоит дотронуться до двериьь шкафа... vyjádřena větší míra obtížnosti a zejména 'jednorázovosti', která souvisí s realizací doteku, srov. např.: Dítě nedosáhne na kliku (tj. 'vztáhlo ruku a uchopilo ji do ruky') Ребёнок не достаёm до ручки. Мám krátké ruce, a nemohu proto dosáhnout na tkaničky bot. Podobně i sloveso касаться vyjadřuje doteky opakované bez trvalého uchopení. Nicméně v češtině může fáze vzniku doteku být i zdrojem pro metaforicky konceptualizované schéma. Tak např. některé ,dlouhodobější / trvalé kontakty, vztahy a okolnosti‘ mohou být konceptualizovány prostorově jako ,nádoba‘ či pouhý 
,objekt‘, srov. situaci v češtině v porovnání s ruštinou: dosáhl na funkci rektora / značného jmění (достичь поста ректора /нажить большое состояние); агта́da zasáhla do konfliktu (армия вмешалась в конфликт). Je zřejmé, že ruské výrazové ekvivalenty se zde konceptualizačně shodují s českými dosti výrazně.

Cílové oblasti, v nichž je / není významově realizován lokalizovaný ,kontakt ruky‘s objektem doteku a jejich metaforické reflexe, srov. např.: presáhnout превысить (выйти за рамки), ,dotknout se něčeho za stanovenou mezí; nedosáhnout / nedohmátnout не достичь / не достать, ,ukončit pohyb ruky před stanovenou mezí'; zasáhnout nonacmb / задemb, ,umístit něco do vymezeného prostoru'; obsáhnout о(б)хватить пальцами / руками, obemknout prsty / rukama určitý objekt'; ohmatat ,hmatáním obsáhnout určitý objekt na vnější / vnitřní ploše“, nejsou v ruštině, s výjimkou posledně uvedeného případu, realizovány ze zdrojové oblasti spojené se sférou dotekových vjemů ruky. Proto i metaforizované významy tohoto typu, v nichž je kritériem lokalizace ve vztahu $\mathrm{k}$ hranici, např. vzdálenost těchto hranic a jejich obsah, se v ruštině pohybují již mimo pojmovou oblast ,kontaktu ruky“, srov. např.: перегиб (промах) přehmat (úředniků, soudců), významový přesah“; rozsah díla объём произведения; оbsah díla содержание произведения. Oba poslední př́klady jsou dvě složky stejného konceptualizačního schématu ,nádoby', nicméně představově prezentují v češtině souvislost $\mathrm{s}$,hmatem', zatímco pro ruštinu je prvořadým zdrojem obecně nerozlišená vjemová percepce a teprve ve druhém z nich jde o poslední segment taktilních procesů, tj. ,držení'. V češtině uvedená fáze taktilního procesu dále motivuje v obecné rovině některé ,vztahy', srov.: nadržovat někomu; držba půdy; údržba stroje, domu apod.

Lze dojít k závěru, že dílčí fragment jazykového obrazu, v němž se jako zdroj profilují pohyby hmatového orgánu ,ruky“ za účelem změny ,lokalizace doteku, popř. hodnocení jeho ,kvality“, je v češtině i ruštině konceptualizován prostorově-orientačním schématem ,špatný je mimo hranice‘. Nicméně zdroje a formální vyjádření metaforických konceptualizací se v obou jazycích odlišují. Ve skupině kognitivních procesů na bázi taktilních kontaktů jsou tyto v češtině významným zdrojem i pro další metaforické schematizace, např. typu ,potrubí'. V cílové oblasti ústí obecně do vztahů, v nichž jsou reflektovány, s ohledem na aktivizaci dílčích částí ,nádoby', jako ,vnitřek', ,povrch', ,obsah', ,hloubka' apod., popř. do různých ,průvodních okolností‘. Rovněž lze identifikovat,směr pohybu', např. brát si úvěr / брать кредит; bereš si to př́liš $k$ srdci / вы принимаете всё слишком близко к cердиy; sebral mi moje myšlenky / он забрал мои идеи (,směr k sobě') a naopak pustil vše z hlavy / он выбросил всё из головы; poušti draka (,směr od sebe') / он запускает бумажную змею, ,vưli‘ živých bytostí, zda chtějí být v něčí blízkosti či nikoli, jako např.: zadržet někoho $\rightarrow$ policie zadržela podezřelého na 48 hodin (,vynucená blízkost pro zadrženou osobu') полиция задержала подозреваемого на двое суток; zápasník přidržoval soupeře na lopatkách (,nedobrovolně zadržoval') бореи прижимал соперника на лопатках, a naopak uvolnění: opustil náš debatní kroužek a přešel do jiného / (,dobrovolně odešel') покинул нашу дискуссионую группу и перешёл в другую; připustil, že jeho názor je zajímavý (,dobrovolně souhlasil s něčím názorem‘) он признал, что его взляды интересны. V uvedené zdrojové skupině lze v obou jazycích pozorovat nejenom značné shody v v nespecifikovanosti taktilního kontaktu rukou, ale i v cílových metaforických realizacích. V nich převažuje konceptualizační schéma ,myšlenky, názory jsou entity'.

Důležitým sémantickým podtypem je ,kvalita držení a ,kvalita uchopení‘. V češtině i ruštině je ,kvalita držení' i ,kvalita uchopení‘, podobně jako ,směr pohybu' konceptualizována běžným schématem ontologické metafory (Lakoff - Johnson: 
47), personifikující slovesný děj. Pro cílovou oblast má čeština několik sloves, z nichž nejfrekventovanější je držet, lpět / держать, липнуть (иепляться). Každé z nich vyjadřuje poněkud odlišnou kvalitu vztahů, přičemž jazyková vyjádření mohou mít různě zabarvené konotace: drži to jako helvitská / židovská víra (держumcя намертво) (Mokienko - Wurm 2002: 582),velmi kvalitní spoj neživých objektů‘; smůla se mu lepí na paty, velký neúspěch'; drži se jí/ho jako veš košile / drží se jí/ho jako klišstě (вцепиться в кого, во что мёртвой хваткой/как клеш) (Mokienko Wurm 2002: 231) ,velmi pevný vztah (hodnocení výrazně pejorativní); prílepil se k nim (пристал к ним как репей), vztah jednoho člověka ke skupině, přičemž zájem na udržení vztahu má pouze dotyčný jedinec' (hodnocení mírně pejorativní). Člověk sám může vyznávat určité hodnoty a názory, srov.: lpí na svém přesvědčení; lpěli na životě do posledního okamžiku, ale pokud je osoba v pozici subjektu nahrazena určitými abstraktními pojmy, jsou získané konotace výrazně záporné, srov.: na rukou ти lpí či krev nevinných lidí (на его руках чья кровь; его руки обагрены чьей кровью) (Mokienko - Wurm 2002: 282); lpí na něm cejch nemanželského ditěte (на нём наложено клеймо незаконнорожденного ребенка).

V cílové oblasti může být pojem ,dlouhodobý kontakt‘ formálně a sémanticky propojen s kořeny -drž-, -chop- a etymologicky prríbuzným -chv-. Významově často vyjadřuje ,trvalost' výsledku doteku a ,následující fáze uchopení'. Přri pohledu z češtiny, srov. např.: zdrženlivý člověk se většinou tváři neutrálně (сдержанный человек) - ,člověk schopný omezit své citové projevy“; zdržovaci taktika je při politických jednáních účinná (тактика замедления) - ,postup mající za cíl co nejdéle konzervovat status quo“ je uvedený prostor konceptualizován schématem metafory ,potrubí'. Deriváty vytvořené od kořene -chop- primárně následují fázi po doteku, kdy je předmět uchopen, což se stává významným zdrojem pro cílovou oblast mentálních činností, srov.: schopný člověk (способный человек), рорг̆. s negativními konotacemi všehoschopný člověk (человек способный на всё плохое); пеschopný пе̌со zařídit (неспособный что-либо оформить). V uvedené cílové sféře mohou deriváty vyjadřovat i poznávací činnosti, srov.: pochopil vše velmi rychle (он понял все быстро); má dobré poznávaci schopnosti (y него хорошие познавательные способности); mít pochopení (понимать); zdravotní stav: lékař vystavil pacientovi neschopenkи (врач выдал пациенту больничный лист); lékar̆ pacienta uschopnil od dalšiho týdne (врач признал пациента трудоспособным со следующей недели); vojenské služby neschopen (к военной службе не пригоден). Jiný okruh derivátů může v češtině vyjadřovat ,kvalitu fyzické (duševní) aktivity‘, srov.: mužstvo se vzchopilo a zvitézilo (SSJČ [VII] 1989: 420) (команда собралась и одержала nобедy). Řadu z uvedených metaforizovaných významů mentálních činností a vlastností v češtině konceptualizujeme jako ontologickou metaforou ve schématu ,schopnost je entita' (Lakoff - Johnson 2002: 39; Machek, V. 1997: 130, 203), přičemž zdrojovou částí je v obou př́ípadech charakteristika kvality taktilního vjemu, konkrétně ,držení a ,uchopení. Ekvivalentní sémantický prostor je v ruštině konceptualizován stejným schématem, zdrojově vykazuje též velkou míru shody, nicméně se liší jazykovými realizacemi.

Kořen -chv- ve svých derivátech vyjadřuje především, vysokou míru a intenzitu fyzického a duševního prožívání děje‘, přičemž zdrojově jazykové reflexe souvisejí s taktilními vjemy, srov.: koně byli schváceni (лощадей загнали); byl uchvácen pestrostí barev (его увлекли пестрые цвета). Rovněž substantivní tvary chvat (приём), záchvat (nристуn) vyjadřují ,intenzitu, rychlost, kvalitu i rozsah děje‘, srv. např̀. ...je značná možnost dostat srdeční záchvat (... получить сердечный npucmyn) naznačuje postižení celého organizmu, ale v ruštině, též ve spojení silniční 
obchvat města (объездная дорога города), se implicitně reflektuje postižení celku, v daném případě lidského sídla; podobně i spojení zápasnický chvat (nриём в борьбе) znamená zasažení celého protivníka. I významová oblast fyzického výkonu člověka spolu s pohybem je v češtině konceptualizována na základě další dílčí fáze po ,doteku' schématem ontologické ,personifikační metafory'. Zdrojově totožnou konceptualizační strategii využívá i ruština, jak je z metafor patrno, nicméně i v tomto př́ípadě dává ruština přednost odlišným jazykovým reflexím.

Podobně jako čeština disponuje rovněž ruština totožnou zdrojovou oblastí v rámci taktilních počitků s jazykovými reflexemi v podobě kořene -XB(aT)-. Má rozvinutou škálu souvisejících slovotvorných derivátů, srov.: xвam obratný, šikovný chlapík (srov. v češtině nář. šmat), ale rovněž xвam hmat (x. снизу-podhmat, x. сверxy - nadhmat); хватать chytati, popadati, chňapati; хватка (хваток) исhореní, hmátnutí; zručnost, grif; хватко šikovně, obratně; хваткость chápavost, vnímavost, obratnost, šikovnost; хваточка, vhodný, šikovný způsob '; хватски odvážně, bujaře, furiantsky; хватский šikovný, obratný, dovedný, zručný, bujarý; yxваm vidlice na vytahováni hrnců z ruské pece; yхватка př́chytka, držák; yхватность šikovnost, zručnost; yxватumb chytit (VRČS 5, 1962: 465). I v ruštině uvedený zdroj taktilních vjemů vyjadřuje ontologické ,personifikační metafory', přičemž cílové jazykové reflexe -chv- v češtině se od ruského -XB(aT)- liší sémanticky a často i formálně. Vytváří se tak odlišná struktura představ, což řadí české i ruské ekvivalenty do odlišných částí jazykového obrazu světa. $V$ češtině jde především o manuální ,zručnost“ a ,dovednost", zatímco v ruštině je sémantika často koncentrována do oblasti ,tělesného a zdravotního stavu a schopností‘, srov: насколько хватает глаз ,co lze uvidět / obsáhnout zrakem '; nороху не хватает (všechen prach již vystř́lel); этого еще не хватало (to (tak) ještě scházelo); хвататься за животы (popadat se smíchy za břicha); хвататься за соломинку (chytat se stébla); хватить через край ,vујаdřovat se neadekvátně situaci'; хватиться за ум, vzpamatovat se'; кондрашка хватил кого (klepla pepka někoho); хватать / брать за душу / сердие ,velmi silně něco prožívat'; схватывать на лету, velmi rychle chápat'.

Ruský kořen -держ- vychází jako český protějšek opět ze stejné zdrojové oblasti a v cílové oblasti je často konceptualizován jako ,metafora potrubí‘, prričemž jazykové realizace sémanticky vyjadřují ,mentální a psychické stavy člověka‘, srov.: держать верх над кем (mít navrch před kým); держать в кубыике (mit penize ve slamniku / štrozoku) ,nepouštět do oběhu (peníze) ${ }^{6}$, держжать в курсе кого ,informovat koho“; держать в мыслях / в уме (mít v hlavě) ,pamatovat si na někoho“; держать в черном теле ,př́sně jednat s někým'; держать камень за пазухой ,myslet a jednat se zlobou a zákeřně‘; держ⿻ать нос по ветру (kam vitr, tam plášt ); держать под крыльикком кого (brát pod křidla) ,pečlivě se starat o někoho“; держать себя: 1) jednat nějakým způsobem; 2) chovat se nějakým způsobem; держсать порох сухим ,být připraven k boji‘; держсать себя в руках - držet se ,ovládat se'; держсать сердие на кого ,mít vztek na někoho“.

\section{Závěry}

V článku se analyzují možnosti vzniku zejména konceptuálních metafor od zdrojů $\mathrm{k}$ cílové jazykové realizaci $\mathrm{v}$ oblasti taktilních počitků, přičemž se berou v úvahu i slovotvorné souvislosti. Sleduje se porovnání česko-ruské. Na základě uvedených poznatků lze zformulovat dílčí závěry do těchto bodů.

1) Celou sféru taktilních počitků jako výchozího zdroje pro jazykové reflexe v obou jazycích lze rozdělit na řadu dílčích zdrojových oblastí, přičemž pro náš výzkum jsme zvolili jako zdroj ruku a spojené s ní dílčí sekvence jednotlivých taktilních úkonů. 
2) Zdrojové taktilní podněty mohou $\mathrm{v}$ obou jazycích dosáhnout $\mathrm{v}$ cílové realizaci shodných konceptualizačních schémat, jako např. rozsah díla объём произведения; obsah dila содержание произведения. Jsou konceptualizačně realizovány schématem ,nádoby‘. Zdrojové segmenty v obou jazycích se liší.

Při shodných zdrojových pojmech, pokrývajících sémanticky odlišné oblasti, v češtině ,zručnost“ a , dovednost‘ člověka a v ruštině jeho, tělesný a zdravotní stav a schopnosti‘, často vznikají konceptuální metafory v totožném schématu ontologické ,personifikační metafory“, jako např. этого еще не хватало - to (tak) ještě scházelo; хвататься за животы - popadat se smichy za břicha.

3) Další taktilní vjemy v ruštině i češtině se nemusejí shodovat ve stejné zdrojové oblasti. Jedná se o ruský kořen -держ-. Tento v oblasti cílové zasahuje sémantické pole ,mentálního a psychického stavu člověka‘ a konceptualizuje jej metaforickým schématem ,potrubí‘. V češtině pozorujeme odlišnou situaci, i když taktilní zdrojová oblast, vyjádř̌ená morfémem -drž- je zde také bohatě zastoupena, ale metafory jsou konceptualizačně velmi pestré, počínaje ,metaforou nádoby' (mit penize ve slamniku ) štrozoku) a konče ontologickou metaforou na bázi ,identifikace prričin' (myslet a jednat se zlobou a zákeřně).

4) Lze uzavřít, že ve srovnávaném česko-ruském materiálu taktilních vjemů jako zdroje pro cílové oblasti metaforických jazykových realizací konceptuálního rázu, existuje řada shod $\mathrm{v}$ rovině zdrojové a jejího formálního vyjádření. Pokud ovšem sledujeme linii korelující sémantické ekvivalence, dostáváme se zpravidla ve srovnávaném jazyce $\mathrm{k}$ výsledkům odlišným. Může se lišit cílová formální jazyková realizace, typ konceptualizačního schématu, případně obojí. Linie shod formálních od zdroje až do cíle oblasti nás zpravidla zavádí sémanticky i představově zcela do jiných oblastí, což ovšem nebylo předmětem výzkumu.

\section{Bibliograpic references}

BARTMINSKI, Je. 2009. Aspects of cognitive ethnolinguistics; edited by Jörg Zinken. London Oakville: Equinox. ISBN 978-1-84553-342-7.

BARTOS, I. 2007. Uvod do teorie rozmazanych mnozin a jejich aplikace pri modelovani jazykoveho regionu. In Region, regionalistika, regionalismus a regionaliste. Ceské Budejovice: Vysoka skola evropskych a regionalnich studii, pp. 8-26. ISBN 978-80-86708-39-3.

JANDA, L. 2004. Kognitivni lingvistika, Cítanka textu z kognitivni lingvistiky I. [eds. Lucie Saicova Rimalova], Prague: UK FF, pp. 9-60. ISBN 80-7308-072-9.

KOROSTENSKI, J. 2011. Jazykove reflexe některych aspektu konceptu 'kontejnerunadoby' v ruštině /s prihlednutím k cestině/. Ceské Budejovice: Vysoka skola evropskych a regionalnich studii. ISBN 978-80-86708-61-4.

LAKOFF, G. - JOHNSON, M. 2002. Metafory, kterymi zijeme. Brno: Host. ISBN 80-7294-071-6.

LANGACKER, R. W. 1987. Foundations of Cognitive Grammar, Volume I, Theoretical Prerequisites. Stanford. ISBN 0-8047-1261-1.

MACHEK, V. 1997. Etymologicky slovnik jazyka ceskeho. Prague: Nakladatelstvi Lidove noviny. ISBN 80-7106-242-1.

MOKIJENKO, V. - WURM, A. 2002. Cesko-rusky frazeologicky slovnik. Olomouc: Univerzita Palackeho v Olomouci. ISBN 80-244-0406-09.

NEBESKA, I. 2007. Voda v ceském jazykovem obraze sveta. In: Obraz sveta v jazyce II. Prague: Univerzita Karlova v Praze, Filozoficka fakulta, Ustav ceskeho jazyka a teorie komunikace, pp. 19-41. ISBN 978-80-7308-213-0.

REJZEK, J. 2001. Cesky etymologicky slovník. Prague: LEDA, spol. s r. o. ISBN 80- 
85927-85-3.

SAICOVA RIMALOVA L. 2007: K jazykovemu obrazu strachu v ceštine. In: Obraz sveta v jazyce II. Prague: Univerzita Karlova v Praze - Filozoficka fakulta. Ustav Ceskeho jazyka a teorie komunikace. ISBN 978-80-7308-213-0.

SLOVNIK SPISOVNEHO JAZYKA CESKEHO (SSJC). 1989. D. II, III, VII. Praha. VANKOVA, I. et al. 2005. Co na srdci, to na jazyku. Kapitoly z kognitivni lingvistiky. Prague: Karolinum. ISBN 80-246-0919-3.

VANKOVA I. 2007. Reč, ktera mluvi (Rec-language jako vychodisko kognitivnelingvistickeho zkoumani a konceptualizace reci v ceskem obrazu světa). In: Obraz sveta v jazyce II. Prague: Univerzita Karlova v Praze - Filozoficka fakulta. Ustav ceského jazyka a teorie komunikace. ISBN 978-80-7308-213-0.

VELKY RUSKO-CESKÝ SLOVNIK. 1959. D. 4. Prague: Ceskoslovenska akademie ved.

ROSCH, E. 1977. Human categorization. In: N. Warren (ed.), Studies in crosscultural psychology, N.Y.: Academic press, vol. 1, pp. 1-49.

ALEFIRENKO, F.M. 2010. Lingvokulturologiya. Cenostno-smyslovoye prostranstvo jazyka. Ucebnoye posobiye. Moskva: Izdatelstvo «Flinta», Izdatelstvo «Nauka» 2010. ISBN 978-5-9765-0813-2, ISBN 978-5-02-034839-4.

VORONINA, T.M. 2012. Obraznaya schema «granica» i jejo leksiceskije reprezentaciyi v russkom yazyke: modifikaciyi prostranstva. In Vestnik Baltijskogo federalnogo universiteta im. I. Kanta. Vyp. 8. pp. 54 - 59.

DAL, V. 1955. Tolkovyj slovar zivogo velikrusskogo yazyka. T.IV. Moscow: Gosudarstvennoye izdatelstvo inostrannych i nacionalnych slovarej.

KORINA, N. 2012. Kognitivnyj potencial slovoobrazovatelnych modelej. OPERA SLAVICA, XXII, suppl. 1, pp. 66-80.

KUZNECOVA, A.I. - EFREMOVA, T.F. 1986. Slovar morfem russkogo yazyka. Moskva: «Russkij yazyk».

RACHILINA, E.V. (ed.) 2010. A byl li koncept? Konteyner i soderžimoye v russkom yazyke // Lingvistika konstrukcij. Moscow: Azbukovnik, pp. 219-246. ISBN 978-591172-032-2.

TICHONOV, A.N. 1985. Slovoobrazovatelnyj slovar russkogo yazyka. T. I., II. Moskva: «Russkiy yazyk».

CERNYCH, P.Ja. 2004. Etimologičeskij slovar sovremennogo russkogo yazyka. T. I., II. M.: Rus. yaz. - Media. ISBN 5-9576-0121-7.

Words: 4488

Characters: 32621 (18, 12 standard pages)

Doc. Mgr. Jiri Korostenski, CSc.

University of West Bohemia

Faculty of Philosophia

Department of German and Slavonic languagues and literatures

Riegrova 11, 30614 Plzen̆

Czech Republik

jkoroste@kag.zcu.cz 